\title{
Fish assemblage structure in relation to seagrass bed in Tidung Kecil Island, Kepulauan Seribu
}

\author{
Nurul Hidayati ${ }^{1,}{ }^{*}$ and M. Suparmoko ${ }^{2}$ \\ ${ }^{1}$ School of Environmental Science, Universitas Indonesia, Salemba Raya No. 4 Jakarta 10430, \\ Indonesia \\ ${ }^{2}$ Faculty of Economics and Business, Universitas Budi Luhur, Ciledug Raya Jakarta 12260, Indonesia
}

\begin{abstract}
Seagrass provides many ecosystem services that are of beneficial to humans, including its role as a nursery ground for some commercial fishes. This ecosystem role depends on the structural complexity of seagrass beds. Yet few studies in Indonesia sought to associate seagrass with fish. The aim of this paper is to determine fish community response to different seagrass bed density. This study was carried out in the coastal waters of Tidung Kecil Island, Kepulauan Seribu. The fish observation was conducted using underwater visual census in stationary point count. The result showed that there were 21 species and $S$. canaliculatus was dominantly found. Fish abundance and fish community diversity index were found to be higher in seagrass beds with high densities compared to the seagrass beds with low density. The results of this study underline seagrass density can impact upon associated fish. This study provides the contribution of seagrass for coastal fisheries as a nursery ground. It is a way to promote the seagrass ecosystem to the society, therefore it can be considered into coastal policy.
\end{abstract}

\section{Introduction}

A healthy ecosystem is a necessary precondition for achieving sustainable development [1]. One of the ecosystems that need to be protected is seagrass. Seagrass as one of the marine ecosystems is highly productive. They provide a source of food and suitable shelter toward physical disturbances and predator for their inhabitants [2]. Specifically, seagrass beds have been viewed as a vital nursery ground for juveniles of many fish species, including commercial fishes [3]. Habitat complexity structure by seagrass vegetation has been considered a major factor responsible for fish biomass and species richness [4]. The more densely covered bed are considered more complex than beds with sparse or patchy coverage [5].

Seagrass beds are spread throughout Indonesia. One of them is Kepulauan Seribu. Yet, information on seagrass fish assemblages in Kepulauan Seribu only a few reported. In 2015, fish sampling was conducted in Pramuka Island using beach seine. A total of 24

\footnotetext{
*Corresponding author: id.nurulhidayati@gmail.com
} 
species of fishes from 15 families was identified. The largest family was Siganidae (4 species) [6].

In the present study, the association between seagrass and fish was investigated. The aim of this study is to determine fish community response to different seagrass bed density. The results are expected to provide baseline data, especially about the contribution of seagrass for coastal fisheries as a nursery ground. It will support seagrass conservation program in Kepulauan Seribu.

\section{Methods}

\subsection{Study site}

The research was conducted in the seagrass area of Tidung Kecil Island, Kepulauan Seribu, Jakarta in July 2018. Sampling was carried out in two stages. The first stage is a preliminary sampling to find out sampling site. The second stage is the main sampling to observe fish in different seagrass density.

The result from preliminary sampling was two sampling sites were selected based on density: dense seagrass (Location 1), and sparse seagrass (Location 2). Both sites are multispecific seagrass beds composed of several species of seagrass. On the site, 5 seagrass species are present: Halophila ovalis, Halodule uninervis, Cymodocea rotundata, Thalassia hemprichii, and Enhalus acoroides.

\subsection{Fish sampling}

The fish observation was performed using underwater visual census with the help of camera in stationary point count. A $10 \mathrm{~m}$ long tape was placed, and all fishes were observed within a $5 \mathrm{~m}$ radius from the center of the tape. The observation was carried out for 15 minutes [7]. The data was collected was the individual number from each species of fish.

\subsection{Data analysis}

The collected data were analyzed to find out ecological indices such as the diversity index of Shannon-Wiener $(\mathrm{H})$, and Dominance (D). Index of diversity was calculated by following the equation:

$$
H=-\sum_{i=1}^{n} p_{i} \ln p_{i}
$$

Where $H$ is an index of species diversity, $p_{i}$ is the relative abundance of the $i$ th species ( $N_{i}$ is the number of the $i$ th species). Index of dominance was calculated by the formula:

$$
D=\sum p_{i}^{2}
$$

Where $p_{i}$ is the proportion of the $i$ th species in a sample. Differences in fish abundance between study sites were analyzed by independent-samples t-test using software package IBM SPSS 22.0.

\section{Results and discussion}

\subsection{Fish composition and abundance}


A total of 700 fishes were collected representing 21 species in 4 families (Fig. 1). The number of species found in this study is higher than in Menjangan Kecil and Menjangan Besar ( 8 and 2 species) [8], but lower than in Tanjung Merah (137 species) [9], and Muara Binuangeun (38 species) [10]. They have higher number of species due to fish collection technique using fishing gear such as beam trawl and net.

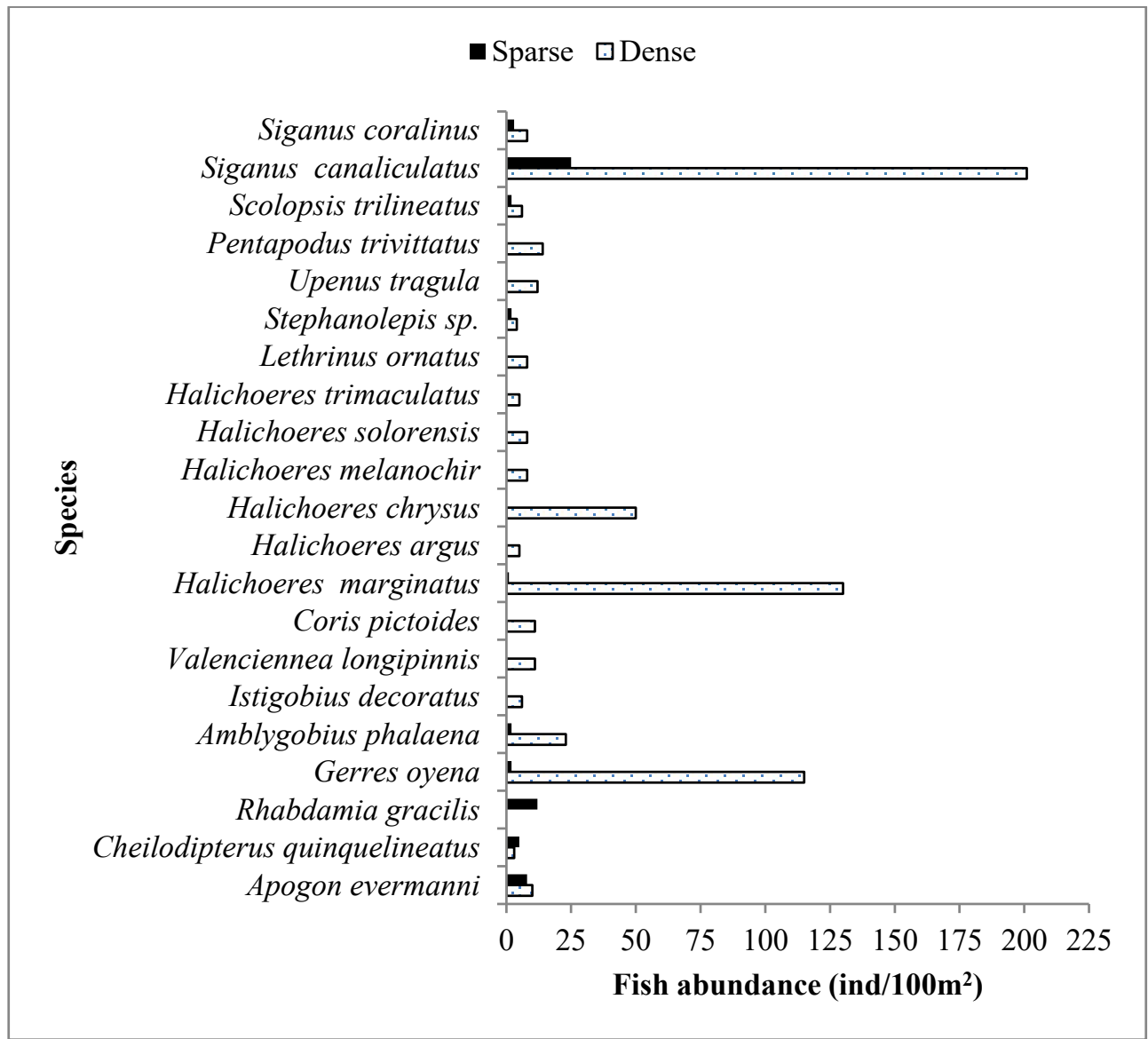

Fig. 1. Fish abundance in Tidung Kecil Island.

The most abundant species in term of number was Siganus canaliculatus $(32,28 \%)$, followed by Halichoeres marginatus (18,71\%), and Gerres oyena (16,71\%). $S$. canaliculatus uses seagrass habitat as a nursery ground. Seagrass E. acoroides has wide leaves that provide shelter from predator attacks and high current velocity. Dense seagrass leaves can inhibit the high intensity of sunlight entering the waters so as to provide shade for the juvenile $S$. canaliculatus. This fish also take the benefit from seagrass, especially $T$. hemprichii as a food source.

Seagrass habitat is used by $H$. marginatus as a feeding area. They eat crabs, echinoid, polychaeta, gastropods, ophiuroid, shrimp, and chiton [11]. Moreover, seagrass is used as protection from predators. One tactic carried out is self-camouflage. H. marginatus can deceive predators with similar body color to seagrass leaves.

Fish $G$. oyena uses seagrass habitat as a nursery ground. The form of nursery ground offered by seagrass bed for $G$. oyena is feeding area. Seagrass beds as a place to attach for 
various epifauna are the right place to find food for G. oyena. This species eats larvae of copepods and polychaeta [12-13].

Number of species that found on dense seagrass habitat was 20 species. It was higher than sparse habitat that only had 10 species. Furthermore, significant differences in abundance of fish among different seagrass density were found $(p<0,05)$. Seagrass bed that has high structural complexity is more valuable habitat for more diverse invertebrate fauna and species of fish than seagrass bed with low complexity [14]. Higher habitat complexity provides shelter from predator, more abundant and diverse prey, and increase the availability of microhabitat. It is especially essential for susceptible juveniles due to structural complexity may be strongly related to survival and growth rates of individual fish [15].

\subsection{Ecological index of fish community}

The ecological index is expressed as numbers or scores that have been derived or transformed from quantitative data. It used to look at the sustainability of communities [16]. The ecological index consisted of diversity and dominance index. The results of data analysis of ecological index fish communities in Tidung Kecil are summarized in Table 2.

Table 1. Ecological index of fish community in Tidung Island.

\begin{tabular}{|l|c|c|}
\hline \multirow{2}{*}{\multicolumn{1}{|c|}{ Ecological Indices }} & \multicolumn{2}{c|}{ Location } \\
\cline { 2 - 3 } & 1 & 2 \\
\hline Diversity & 2,120 & 1,808 \\
\hline Dominance & 0,183 & 0,203 \\
\hline
\end{tabular}

Diversity index can describe the level of stability. The value affected by two basic factors, namely the number of species (species richness) and the relative abundance of species (species evenness) [17]. The results, as shown in Table 2, indicate that the location of dense seagrass has high diversity $\left(\mathrm{H}^{\prime}>2\right)$ and the sparse seagrass has moderate diversity $\left(1<\mathrm{H}^{\prime}<2\right)$. Fish on the location of dense seagrass has higher diversity due to number of fish found is higher than sparse seagrass.

Dominance index is used to see the existence of dominant species in a community. The index value ranges from 0 to 1 . The greater index value is indicated the more likely their one dominant species. From the results, domination index on sites is included in the low category, accordingly can be interpreted there is no certain species which dominates the region.

Considering the calculation results, fish on the location of dense seagrass have more stable community than the sparse one. It can be explained by high diversity index $\left(\mathrm{H}^{\prime}=\right.$ $2,120)$ and low dominance index $(\mathrm{D}=0,183)$. This study has compared the diversity and abundance of fish community structures with different seagrass bed densities. Further research should be done to investigate the fish assemblages structure in seagrass beds in relation to temporal variations.

\section{Conclusions}

In conclusion, we find that seagrass density can affect fish structure community. The fish density was higher in dense seagrass than sparse seagrass habitat. Higher diversity index and lower dominance index was found in dense seagrass habitat. The results of this research support the idea that seagrass habitat conservation is important to maintain overall biodiversity and the sustainability of local fisheries. 


\section{Acknowledgements}

The authors would like to thank Universitas Indonesia for support our research under grant scheme Hibah Publikasi Internasional Terindeks untuk Tugas Akhir Mahasiswa (Hibah PITTA) Research Grant Contract No. 2581/UN2.R3.1/HKP.05.00/2018.

\section{References}

1. A. J. Reid, J. L. Brooks, L. Dolgova, B. G. Sullivan, P. Szekeres, S. L. R. Wood, J. R. Bennett, S. J. Cooke, Environmental Science and Policy 77, 179 (2017)

2. F. Jordan, M. Bartolini, C. Nelson, P. Patterson, H.L. Soulen, Journal of Experimental Marine Biology and Ecology 208, 45 (1997)

3. F. Tuya, R. Haroun, F. Espino, Ocean \& Coastal Management 96, 181 (2014)

4. M. Hori, T. Suzuki, Y. Monthum, T. Srisombat, Y. Tanaka, M. Nakaoka, H. Mukai, Mar Biol. 156, 1447 (2009)

5. J. R. Rooker, S.A. Holt, M.A. Soto, G. J. Holt, Estuaries 21, 318 (1998)

6. F. Amin, M. M. Kamal, A. A. Taurusman, Jurnal Ilmu dan Teknologi Kelautan Tropis 8, 187 (2016)

7. N.V.C. Polunin, C.M. Roberts, Mar. Ecol. Prog. Ser. 100, 167 (1993)

8. E. S. Susilo, D. N. Sugianto, Munasik, Nirwani, C. A. Suryono. IOP Conf. Series: Earth and Environmental Science 116, 1 (2018)

9. A. Syahailatua, S. Nuraini, Mar. Res. Indonesia 36, 1 (2011)

10. N. Kholis, M. P. Patria, T. Soedjiarti, AIP Conference Proceedings 1862, 030119 (2017)

11. J. E. Randall, Food Habits of Reef Fishes of the West Indies (Hawaii Institute of Marine Biology University of Hawaii, Honolulu, 2004)

12. S. Hajisamae, L. M. Chou, S. Ibrahim, Environ. Biol. Fish 520, 61 (2004)

13. K. Nanjo, H. Kohno, M. Sano, Fisheries Science 74, 1024 (2008)

14. R. M. McCloskey, R. K. F. Unsworth, PeerJ. 1053, 1 (2015)

15. M. Horinouchi, M. Sano, Ichthyol Res. 48, 179 (2001)

16. P.J. Fedor, I.F. Spellerberg, Shannon-Wiener Index in Encyclopedia of Ecology (Elsevier Science, Amsterdam, 2008)

17. M. C. Molles, Ecology: Concepts and applications (The McGraw-Hill Companies, USA, 1999) 